\title{
A REVIEW OF PERFORMANCE HYBRID PHOTOVOLTAIC/THERMAL SYSTEM FOR GENERAL - APPLICATIONS
}

\author{
Author(s): \\ M.H.R. Alktranee
}

\author{
Affiliation: \\ Department of Mechanical, Technical Institute of Basrah, Southern Technical University, Basrah, Iraq. \\ Email address: \\ mohammed84alktranee@gmail.com
}

\begin{abstract}
Photovoltaic modules can generate more electricity when receives a big quantity of solar radiation, but the efficiency of (PV) modules will drop when the temperature of solar cells is high. Therefore, reducing the high temperatures of (PV) modules will contribute to increase the electrical efficiency of (PV) modules by extraction the thermal energy associated with the PV modules and achieve an appropriate conversion efficiency of (PV). The aim of the study in this paper is to recognize the performance of hybrid $(\mathrm{PV} / \mathrm{T})$ systems in different places, conditions, module designs which can be used in household applications, hotels, etc. Aiming to supply of electricity and thermal energy. The study indicates to use of cooling technique (water or air) to cooling (PV) modules will contribute to a large extent to strengthen the work of solar cells and the efficiency of (PV/T) system as well. And the rate return of the system of electricity and thermal energy will increase, especially when the hybrid photovoltaic/ thermal (PV/T) solar systems were properly designed and the conversion rate of absorbed solar radiation for (PV) modules will increase as well.
\end{abstract}

\section{Keywords}

Photovoltaic, Thermal energy, PV efficiency, Solar radiation, Combisystem.

\section{Introduction}

Hybrid photovoltaic/thermal system experiencing rapid growth which provides simultaneously both electrical and thermal energy making it interesting for many applications [1], For that many researches has been conducted in developing and improving the performance of the system by increasing its efficiency, use (water or air) as a technique to cooling solar cells the temperature reaches high levels and the negative effects on the work of the solar cells will appear [2]. This system contributes to reduction of environmental problems by reduce $\mathrm{CO} 2$ emissions are needed in houses and buildings and concentrate on use renewable energy that should be more actively [3], the amount of energy that produce from hybrid $\mathrm{PV} / \mathrm{T}$ system depend on the photovoltaic which convert only a small part of the absorbed solar radiation into electricity and type of solar cells use, where the greater part of solar radiation converted into heat and that lead to increasing their temperature and decreasing their electrical efficiency [4], Hybrid $\mathrm{PV} / \mathrm{T}$ system produces electricity and heat (air or water preheating), that will contribute to improve efficiency of $\mathrm{PV}(/ \mathrm{T})$ modules by extracting the heat loose by using (air or water) as a removal fluid and take this advantage for using in many applications [5]. Several study have been done about using air or water $\mathrm{PV} / \mathrm{T}$ systems some of research found that use water systems seem desirable because of the nature of this fluid allowing better recovery of the heat [6], while other researches find that the results from an applied air type $\mathrm{PV} / \mathrm{T}$ system gives a variety of results regarding the effect of design module and operational parameters on the performance of air type $\mathrm{PV} / \mathrm{T}$ systems [7, 8], where can use the air to cool the surface temperature of the PV panel after pick up the surface heat which can use for household application, drying and other industrial purposes [9]. To ensure solar cell operate at low temperature and keep the PV module efficiency at a sufficient level, where used natural or forced (air or water) circulation as a simple method to remove heat from PV modules, but this method is less effective, especially if the ambient temperature is more than $20^{\circ} \mathrm{C}$, to overcome that can be extracted the heat by circulating (air or water) through a heat exchanger that is mounted at the back 
surface of the PV module. Where PV/T systems provide a higher energy output than standard PV modules and could be cost effective additional to that thermal unit is low [10-12]. These systems which working as solar active devices need requires to good oriented surfaces that towards the equator by suitable orientations on the surface must be exploitation for each square meter with orientation in order to achieve maximize the energy yield with keep the efficiency in suitable level [13]. Therefore, numerous researches done on the analytical and experimental studies of PVT systems in different places and conditions, intended to find out the methods that Contribute to increase the efficiency of these systems [14].

\section{Behavior of hybrid photovoltaic/thermal system by using water}

\section{Modeling and simulation of hybrid PV-thermal solar system by use TRNSYS}

The hybrid photovoltaic/thermal system which can provide at the same time both electricity, thermal energy and according to Cyprus conditions, it has worked both of "Soteris and Kalogirou" by used the system it has been modeled using TRNSYS. Where the system consists of collection of series of PV panels included on a normal PV panel at the back of the heat exchanger fixed fins, a battery, an inverter, hot water storage for thermal system, pump through experiments daily, monthly and performance that done by the system. The results show that the average annual efficiency of the PV solar system was between $2.8 \%$ to $7.7 \%$, thus increasing the mean annual efficiency of the system to $31.7 \%$. And the best water flow rate of the system was $25 \mathrm{l} / \mathrm{h}$. That would cover $49 \%$ of the hot water needs of a house [15]. A hybrid system which could be generating both electricity and hot water warming, it has been modeled number of cases in order to improve the water flow rate to collector. The outcome found that the electricity produced from the PV panel increases with the flow rate increases. Also, the outcomes show the primary value corresponds to $25 \mathrm{l} / \mathrm{h}$, which mean low flow rate value for the system can be used in a thermosyphon module without depending to use a pump and which will improve the economic feasibility of the system [16].

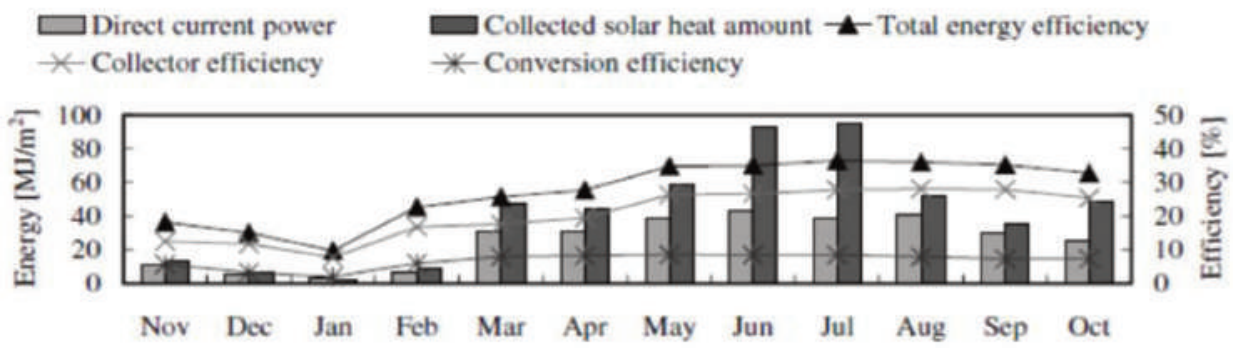

(a)

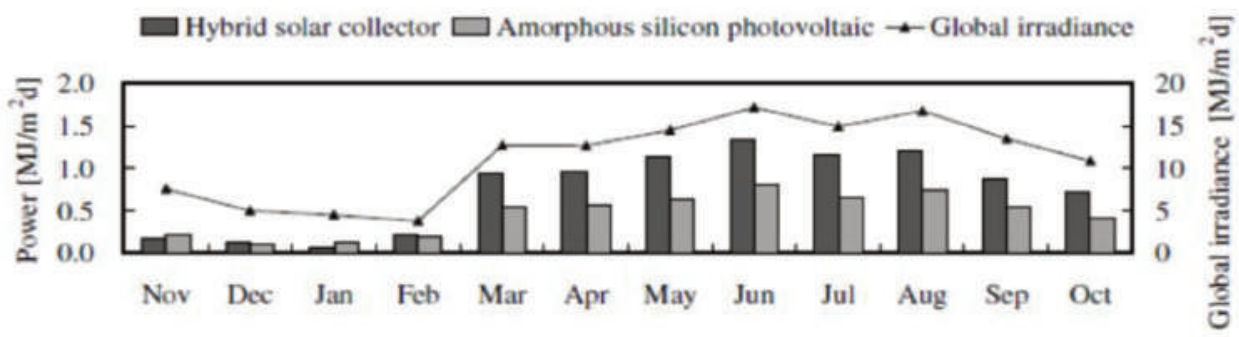

(b)

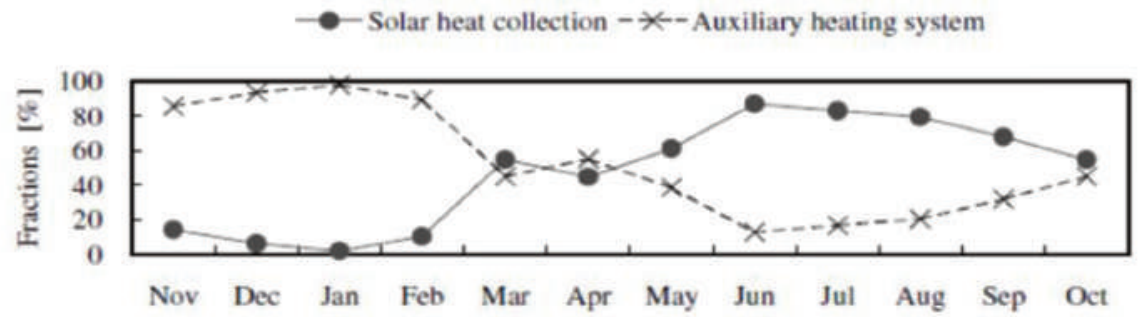

(c)

Figure 1. Field experimental results of the hybrid solar collector: (a) operating results of hybrid solar collector, (b) alternating current power generation, (c) heat fractions for domestic hot water supply [3] 


\section{Perform experiments on a hybrid $P V / T$ solar collector}

Conventional flat plate collector solar thermal with $\mathrm{PV}$ cells composite working in the absorption solar radiation for the output of both electrical and thermal energy, has removed the heat from PV cells that led to higher electrical efficiency of the photovoltaic and useful thermal energy extracted from one of the ends the ducts [17], as well as conducted tests and analyzes on performance the hybrid $\mathrm{PV} / \mathrm{T}$ system which generation electricity and thermal both, this experiment done by constant temperature processing of marinade made. Where found that the conversion efficiency ranged from $10 \%$ to $13 \%$, and collector efficiency was from 20 to $40{ }^{\circ} \mathrm{C}$ marinade than $40 \%$ heat and $50 \%$ and about $20 \%$ of successive [3]. Although there was reduced of collector efficiency, it has compared the efficiency of the hybrid solar collectors for this photovoltaic solar collectors, where were reads in the observational results of this study annual operation to assemble solar hybrid and the Figure 1a below show the maximum monthly amount of current energy $45.3 \mathrm{MJ} / \mathrm{m}^{2}$ in June, and the minimum $2.8 \mathrm{MJ} / \mathrm{m}^{2}$ in January, it means conversion efficiency groups.

Where stabilized about $25-28 \%$ with the exception in the winter season, it was stable at around $8-9 \%$, only in the winter and the maximum value was $28.1 \%$ in august. In Figure $1 \mathrm{~b}$ shows the difference monthly, current energy of the hybrid system and amorphous silicon photovoltaic per unit area of the panels 0.7 and $0.4 \mathrm{MJ} / \mathrm{m}^{2} \mathrm{~d}$, respectively, with the value of hybrid solar collector energy it was about $80 \%$,A Where the efficiency decreased because snow due to thickness of snow in Figure 1c below shows the monthly and annual variation of provider of domestic hot water energy, where it was $13.1 \mathrm{GJ}$ which was comparable to that value for the flat plate solar collector $46.3 \%$ [3].

\section{Production electric and thermal energy of hybrid $P V / T$ solar systems}

Exploitation the amount of energy from hot water and electricity led to motivate many researchers to develop the performance of hybrid PV/T system in order to maintain the electrical efficiency of photovoltaic cells at the adequate level at high temperature, it is necessary for the operation of PV modules at low temperatures by using natural or forced air circulation simple and low-cost methods for transferring heat from the PV modules [18, 19]. The study was conducted at three sites in different regions of, Nicosia, Athens and Madison. As well as used in this study the prototype from polycrystalline silicon (PC-Si) and amorphous silicon (a Si) and used to analysis the outcome a simulation TRNSYS. However, during the test found the production of electric power from the hybrid system is less than standard PV modules (maximum 38\%) units Si PV gives increased total energy production compared to Si PV modules, Nevertheless, the contribution of solar energy to heat water rising in cold climates. Results showed and PC-Si cells produce more electricity (PEL) than identical a-Si cells, this due to higher efficiency of PC-Si cell. The a-Si cells produce more useful thermal energy at all three sites into Madison, Nicosia and Athens. The outcomes indicated that the electricity yield of solar system employing polycrystalline solar is more than that employ these amorphous, but the solar thermal contribution a little less. PV is a hybrid system produces about $38 \%$ of electric power and the domestic thermosyphonic system effective and largest system appropriate for residential construction or low office buildings [20].

\section{Use direct solar floor for hybrid PV/T collectors to experiment Energy performance}

The energy performance of water hybrid PV/T collectors where worked on this application both of Sorensen, Monroe, it has applied on combisystems of direct solar floor type. The target of this study was to take advantage of the hybrid solar collector to achieve maximize the contributions of solar energy to generate electricity and thermal profits useful. This application operates in the integration of photovoltaic (PV) modules in buildings allows one to view the multifunctional and then to trim back costs by replacing frame ingredients, used with this application amorphous cells or composed to improve the thermal output PV/T collector. To consider that hybrid PV/T solar water collectors as a one piece that including thermal absorption the heat exchanges and PV functions, by one day in summer (June) noticed the PV cell temperature there are evolving in their efficiency when the cell temperature increases, also in their efficiency which strongly dropped decreases from $7 \%$ to 4\% [21]. As shown in Figure 2. On the same day the cell efficiency was stable around $8.4 \%$, which represents a reduction of $28 \%$ and the annual efficiency of the conventional photovoltaic component was $9.4 \%$. This is obviously due to the high temperature on the cover and the incident radiation on the PV cells decreased due to glass cover. It has found that without a glass cover the efficiency was $10 \%$, this is $6 \%$ more in effect than a standard module because of the cooling effect [22]. Thus, it has gone from the traditional combisystem associated 
control system which purports to extend the solar thermal energy output. As well as for heating water in homes by the water glycol flow in the back side of the PV modules. It has considered that at least one of the two hybrid solutions (with covered or not) is more efficient than the traditional one $(\mathrm{PV}+\mathrm{T})$, in order to avoid the reduction of the age of solar hybrid assembly found two choices. The first one is obvious to imagine the collector is covered and the second is to study the PV modules which can be stable at high temperature [23].

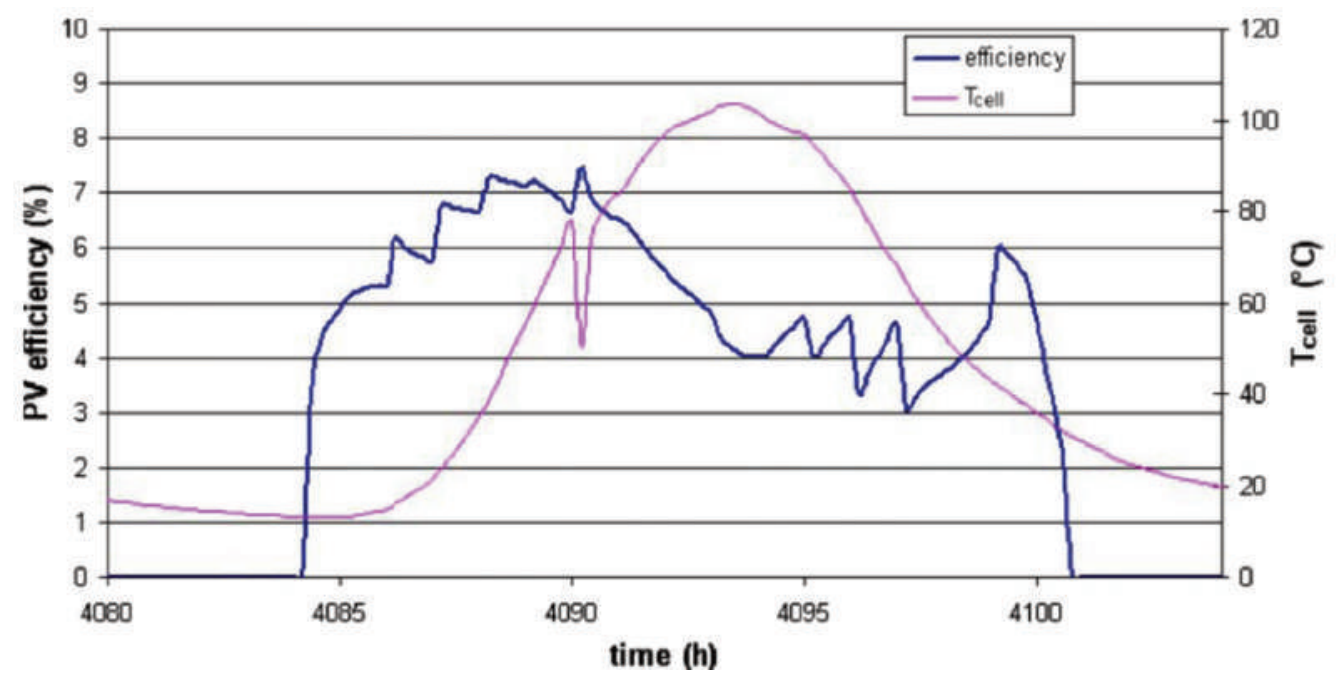

Figure 2. The PV cell temperature and efficiency evolutions [22]

\section{Energy generation with a photovoltaic (PV/T) solar hybrid system}

Many combinations of electricity generating solar systems and heat generating have been studied to cover the needs in large quantities to a residential house typical for a family without any fuel cost with average daily consumption of electric power for domestic about $7 \mathrm{kWh}$. Where the hybrid system consists of (PV) module and compound solar thermal collector energy are constructed and tested for energy collect, the study was conducted in Cyprus have comparatively high averages of exposure solar radiation throughout the year, hot summer days somewhat and for long periods and mild winters to some extent [24]. Depending on the type of solar cells with occupies an area of about $10 \mathrm{~m}^{2}$, found that the amount of energy can be produced in electric with a $1600 \mathrm{~W}$ (PV) system. Therefore large area solar modules will absorb large amounts of solar irradiation, so that will causes loss at the same time in heat units, it has examined experimentally some of hybrid system and found that when using of a booster diffuse reflector will contributed increased the performance of the system and gave giving possibilities for more active for practical applications take the benefit of absorbed solar energy which is not converted into electricity to utilized for thermal applications [25]. A result of this excessive heating of the modules will led to reduction of conversion unit's efficiency, for this reason some of this type does not convert $80-95 \%$ of the energy collected to electricity to remove the extravagant heat. many systems have been designed to use it as an energy source for some other applications like household and industrial applications. As will found that the structure of the unit required some adjustment like to allow to distribute the medium cooling in order to the heat extraction when it is heat fluid transfer system either air or water and to enable watertight and corrosion free construction used water need a more overall amendments [26], The results obtained from these study PV modules absorb a significant sum of solar radiation that generates unwanted heat; however, this loss represents only $1 \%$ of the energy 7 $\mathrm{kWh}$ that is consumed by the typical family the proposed hybrid system produces thermal energy roughly $2.8 \mathrm{kWh}$ per day. That led to total loss about $11.5 \%$ in electric power generation, because the different parts that are placed over the hybrid modules. The payback adjustment period was less than 2 years old, the low investment cost and pay back a relatively short period makes this hybrid system economically attractive, add to that, these hybrid systems that combine to produce electricity and hot water from one system in the same time [27].

\section{Performance of a hybrid photovoltaic/thermal (PV/T) under active solar}

A simple design of hybrid (PV/T) double-slope active solar still has been fined and its performance is 
evaluated in field conditions, the solar energy productively still can be improved by increasing the temperature of the water in the solar energy is still one of the parameters, where it has designed, manufactured and evaluates the performance of a hybrid photovoltaic thermal system (double slope of the active solar still) and modifies the photovoltaic/thermal (PV/T) dual-slope active solar energy is still designed and fabricated to remote sites. And under field conditions in the natural circulation and forced mode (series and parallel), It had been experimented evaluating performance in order to improve the productivity of a dual slope solar energy solar still [28]. The water pump has been used between solar and photovoltaic (PV) integrated flatpanel collector for re-circulation of water during the collectors and converted into solar still, from Figure 3 noted that the daily energy efficiency of $17.4 \%$ was gained for the parallel forced mode arrangement and higher than the series $(16.4 \%)$ and of the natural circulation models (16.3\%), still will produce a higher yield than the other configurations and obtained as $7.54 \mathrm{~kg} /$ day for each hour exergy efficiency is also found to be highest for the same shape and hit as high as $2.3 \%$. The comparative yield obtained is about 1.4 times higher than that obtained for hybrid $(\mathrm{PV} / \mathrm{T})$ single slope, solar still, also found that the total cost of the fabricated still is about $14 \%$ less than hybrids (PV/T) single slope, solar still and the price will be further reduced substantially once production is held up on a commercial scale [29].

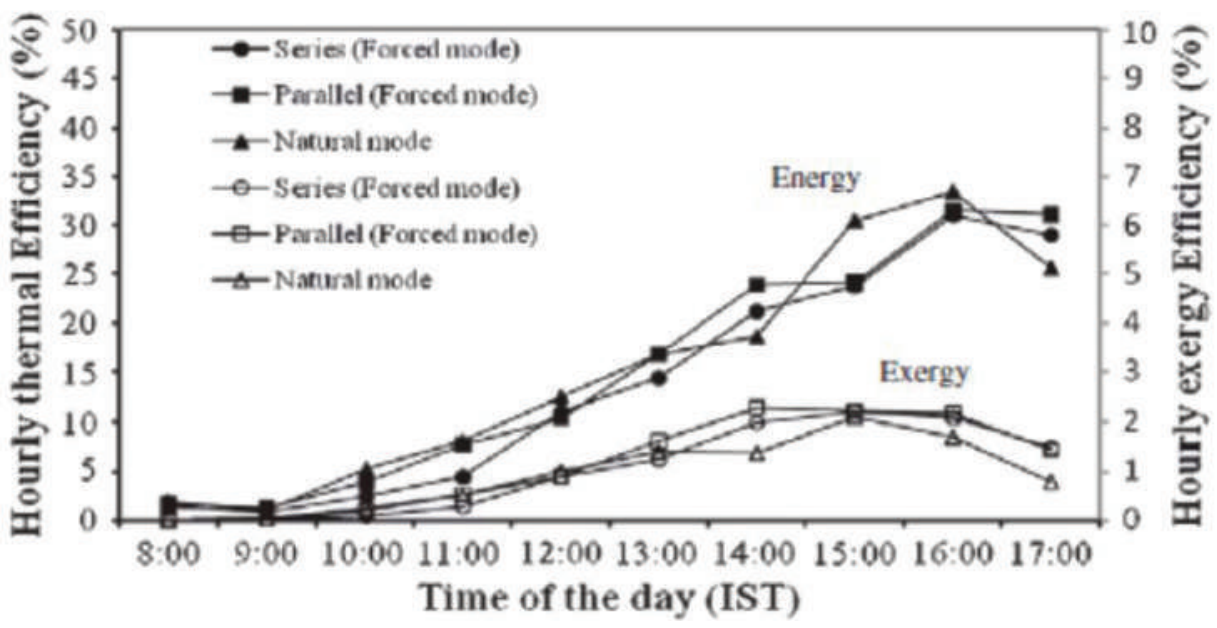

Figure 3. Hourly variation of thermal and exergy efficiencies of solar still during sunshine in different functional styles of hybrid double slope active solar still [29]

\section{Application simulation of solar heating on hybrid photovoltaic/Thermal collectors (PVT)}

To achieving the solar energy which can offer a suitable solution for the electricity and heat in solar panels and/or photovoltaic thermal panels because in this system of electricity production is specially priority for fields that do not have potential high solar energy, where totally recognize that the cell temperature affects on operate photovoltaic panels and efficiency which limits the growth of photovoltaic panels, Nevertheless, suggested one good solution to analyze the hybrid operation of PV/T integrated system that increase solar contributions for electricity and useful thermal profits [10]. Based on the energy and transfer of exergy analysis will use cooling cell panel as a resolution in the photovoltaic thermal $(\mathrm{PV} / \mathrm{T})$, where it is obtained on both electricity and warmth (air and water) as the heating fluid in the PV/T collectors which can be used for heating purposes or in industrial applications, it is necessary for the performance of PV modules at low temperature will dilute the value of the gain heat and the efficiency of exegetic will be very small [30]. Used TRNSYS platform simulation PV/T system, cogeneration heating, established to look at the system performance of solar PV/T where in a typical day studied production of electrical energy from the collector $\mathrm{PV} / \mathrm{T}$, heat consumption, the exit temperatures of assistance the heat source and outlet temperatures from the heat storage tank as Figure 4 below shows the change graphs inlet and outlet temperature of $\mathrm{PV} / \mathrm{T}$ collector work the fluid with solar radiation intensity the ambient temperatures in a typical day in the heating season. The average temperature outdoors was $-4.6^{\circ} \mathrm{C}$, and approach the highest solar radiation intensity $370 \mathrm{~W} / \mathrm{m}^{2}$, and the difference in the inlet and outlet temperature of the 
working fluid inside collector $\mathrm{PV} / \mathrm{T}$ increases with an increase in the intensity of solar radiation, the maximum difference in the inlet and outlet temperature appear in 12 , which reaches $5.42{ }^{\circ} \mathrm{C}$. After the flow of water through the collector the collector heat dissipation to the environment as it is able to earn more heat, in Figure (5) below shows the changes in heat consumption, outlet temperature assistant heat source, the outlet temperature of heat storage tank in the collector system along with changes in ambient temperatures in the outdoor, the startup assistant heat source is consistent with changes in ambient temperatures outdoors, temperature of the working fluid in the heat storage tank to meet the demand of pregnancy, when the value of the highest solar radiation, heat storage tank will get more heat. The results of this study can be seen from the results of the simulation direction operating for the full year in the system to $\mathrm{PV} / \mathrm{T}$ collector $32 \mathrm{~m} 2$ in size in the system can achieve annual energy production $4195 \mathrm{kWh}$, which means that the unit square meters of collector $\mathrm{PV} / \mathrm{T}$ can output $131 \mathrm{kWh}$ electricity annually, through the analysis of simulation results found the heating season that the solar part of the solar heating system is $31.7 \%$, which is close to the design value of $30 \%$ [12].

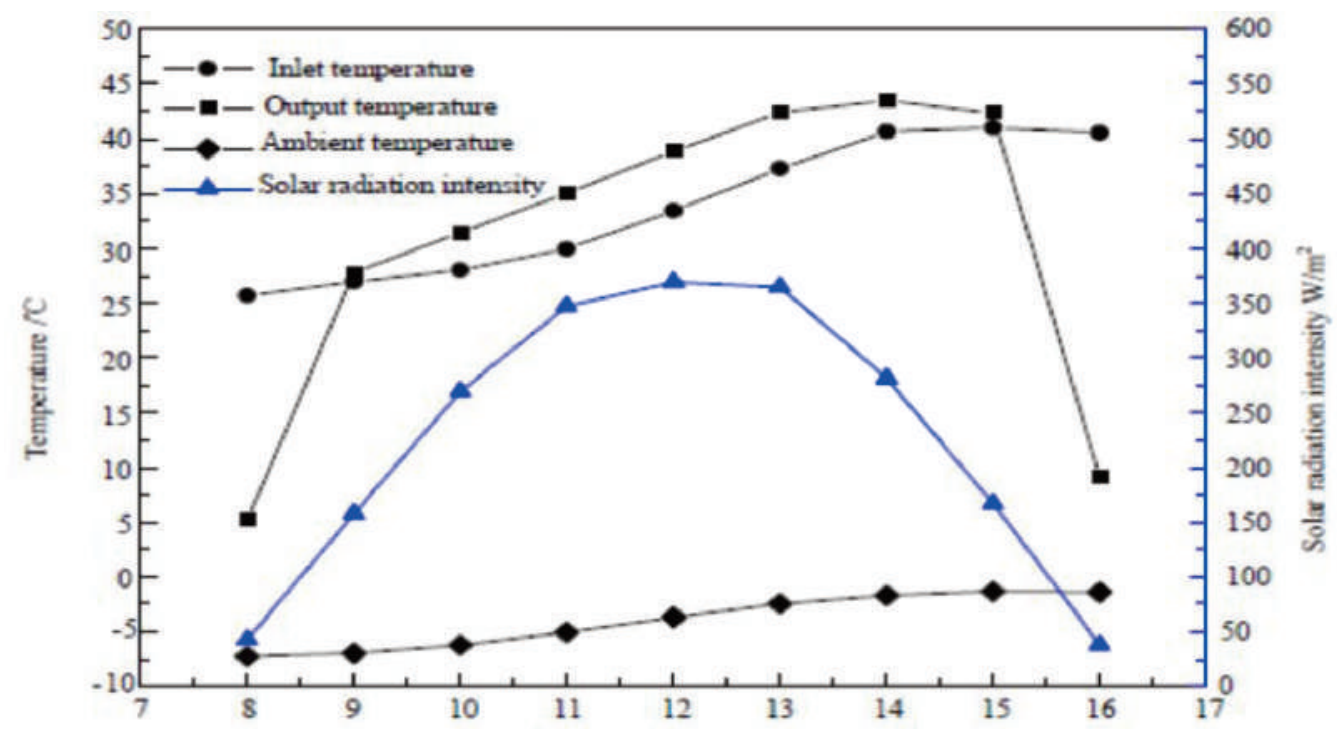

Figure 4. Graphs of the inlet and outlet temperature of PV/T collector working fluid with solar radiation intensity [12]

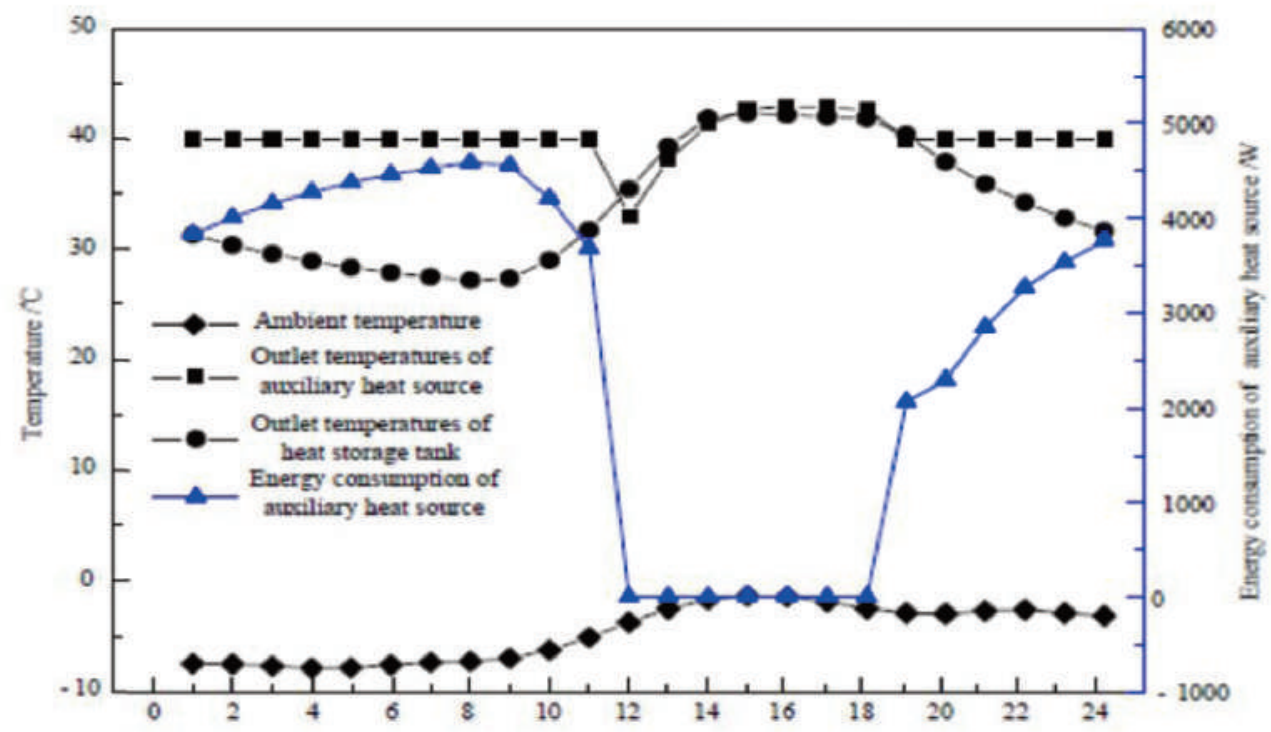

Figure 5. Graphs of heat consumption outlet temperatures of auxiliary heat source and outlet temperatures of the heat storage tank with outdoor ambient temperature [12] 


\section{Behavior of hybrid photovoltaic/thermal system by using water and air}

\section{Considerations about Design for flat-plate photovoltaic/thermal collectors}

Several investigations have been conducted on flat plate $\mathrm{PV} / \mathrm{T}$ collector in theory, as well as, the experience of development of cogeneration components such PV thermal (PV/T), which consists of a combination of photovoltaic (PV) cells and solar thermal energy. This is one of the causes behind the great total of research underway on the growth and integration of solar active devices in the building envelope, where the flat plate collectors $\mathrm{PV} / \mathrm{T}$ can be split into various categories, for instance according to the nature of the heat transport medium (air or water) and there is an additional glass cover (covered and non-covered collectors) [13], In this design have been integrated two main types of solar active devices to produce energy into the building thermal solar collectors to convert sunlight into usable heat and photovoltaic $(\mathrm{PV})$ panels to convert solar radiation into electrical [19], found that relatively low conversion efficiency of photovoltaic cells (usually in the range 10-20\%), and the cells have a high absorption of all the sun's rays, leading to most of the solar radiation absorbed by the PV cells in heat transfer will increase the cell temperature, therefore the reduced efficiency. For evaluation of solar radiation absorbed by a c-Si solar cell and to evaluate the percentage of solar radiation converted into electricity performed measurements on commercial solar cells. It was a reflection of the spectrum and the spectral response of the cell was measured and is summarized in Figure 6 it absorbs about $90 \%$ of the radiation from the inside of the cell while only $15 \%$ is converted to generate electricity $[10,12]$. Solar thermal energy absorption components can provide more effective solutions by beneficial capturing the heat produced in the PV cell and PV cell temperature $\mathrm{PV} / \mathrm{T}$ collectors represented in case use of solar energy [31]. During Comparison between thermal hybrid systems in the building and the operating with the standard solar system and through simulations using TRNSYS, where tests showed the thermal efficiency is almost up as a good complex solar thermal and electricity efficient almost as high as the standard PV panel of the same quality and mode these active solar devices need a well-directed surface, usually towards the equator. Nevertheless, these surface areas on the surfaces or interfaces with limited suitable orientations, in order to maximize energy production, every square meter is available with suitable for solar applications orientation and should be used in the most effective way possible and that lead to an improvement in the thermal and electrical performance [32].

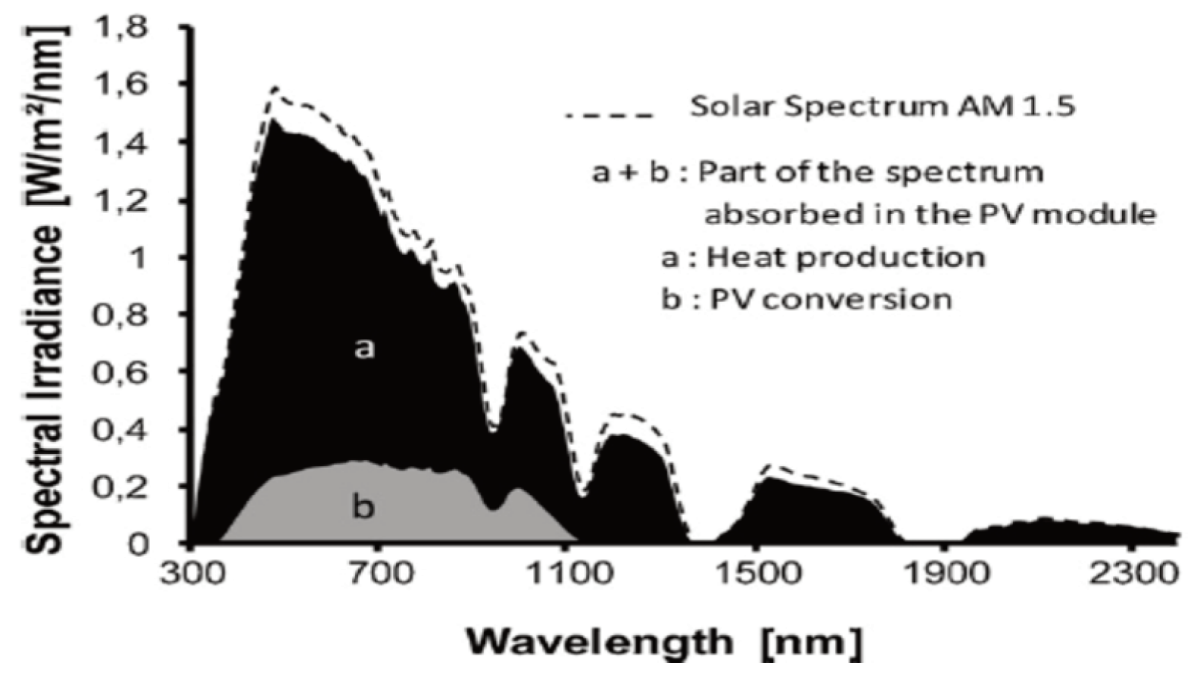

Figure 6. Spectral representation of the absorption, reflection and PV conversion of real c-Si solar cell [13]

\section{Temporal analysis of PV/T solar system for generation of electricity\& thermal (hot air/water) energy}

To get electric and thermal energy simultaneously during use a appliance which has been developed and new hybrid systems commercially as photovoltaic/ thermal collectors, the system has been designed according to type and size of the solar cells which are identical with requirements of the environment, depends on the design of particular solar collectors, either water or air can be used as medium and works 
as a carrier of heat it depend on the usage [10], this idea was based on two parts, the photovoltaic technology that derives from the solar cell technology and converted into electrical energy, and solar thermal technology, which is derived from the thermal collector and convert solar energy into thermal energy [33], where expected that lead to improve the performance with low cost of production and technology of the new energy future technological developments in the use of solar energy. The hybrid system (PV/T) designed to generate thermal and electricity simultaneously and utilization of a hybrid system can offset the need for an outside source of electric power it was experimental conducted in many cases.

1- (Double, pass PV/T collector with fins): As shown in Figure 7 this collection includes three main components: glass cover on the top, panel with photovoltaic cells and absorber at the bottom. The fins were fabricated using aluminum sheet to increase the ability to remove heat from PV cells and thus increase the efficiency and air was flowing through the upper part in the middle of glass cover and PV Panel and then going through the lower part below for PV panel.

2- (Single pass PV/T collector with V-groove absorber) in Figure 8 below shows the schematic diagram of this design, the PV plate is exposed to the sun, which later absorbs the heat and gain electricity simultaneously. By doing this, more heat can be transferred to the air and the PV plate becomes cooler without altering the shape of any Commercial PV module Based on the previous design, the efficiency of the electricity is reduced more than $50 \%$ when the PV plate is covered by the glass.

3 - (Double, pass PV/T collector with fin and CPC): As shown in Figure 9 below the parabolic concentrator (CPC) was added to increase the efficiency of the collector. The air flow as the same way as the collector with fins, but the solar irradiance increased using CPC. Fins attach underneath the PV cell help to remove the heat from a PV panel.

4 - (PV/T collector with rectangular tunnel absorber): As shown in Figure 10, the PV/T collector with rectangular tunnel absorber has the same functions and targets as other collectors, which is, to increase its efficiency. The main difference in this collection is the shape of the absorber with is in a rectangular design.

5- (Water based PV/T collector): The water based $\mathrm{PV} / \mathrm{T}$ collectors are one of the research that being studied at the solar energy research institute. The principle of water based $\mathrm{PV} / \mathrm{T}$ is similar to the air based collector where cold water is practiced as a medium to soak up heat from the sunlight which is later can be used for low heat temperature processes [34]. Some various designs of PV/T collector based on water and air, every design had its own specific way of converting solar energy to electricity and thermal energy simultaneously, where preserve PV module in the current market showed enough potential in application, but these PV modules can only provide electrical energy by changing the preserve PV module with some specific modification, can thus produce electrical energy and caloric energy with the new blueprint of this $\mathrm{PV} / \mathrm{T}$. It is well known that using a hybrid system can eliminate the need for an external source of electrical energy, new technology developments in solar energy utilization are expected to result in the improvement of the photovoltaic performance with lower production cost. This will increase the demand and viability of commercial applications [35].

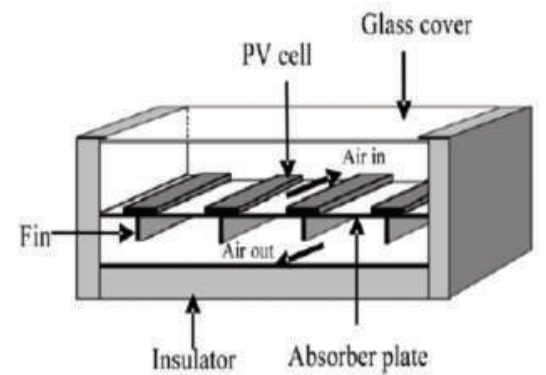

Figure 7. The schematic diagram of double pass $\mathrm{PV} / \mathrm{T}$ collector with fins [33].

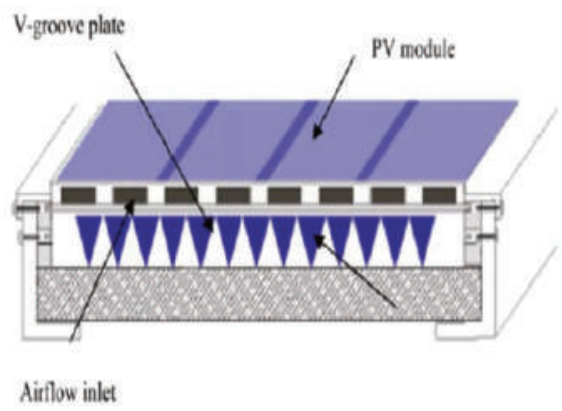

Figure 8. Schematic diagram of the PV/T collector with $\mathrm{V}$ groove absorber collector [33].

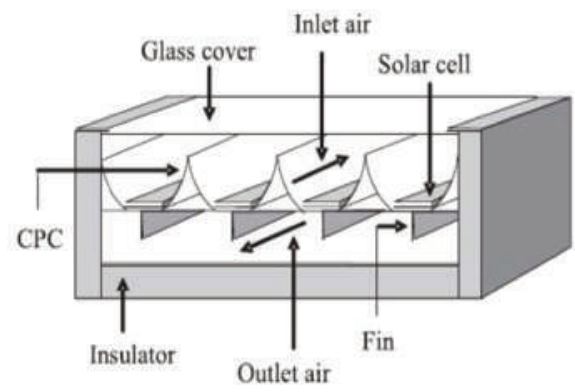

Figure 9. Schematic diagram of double pass PV/T [33]. 


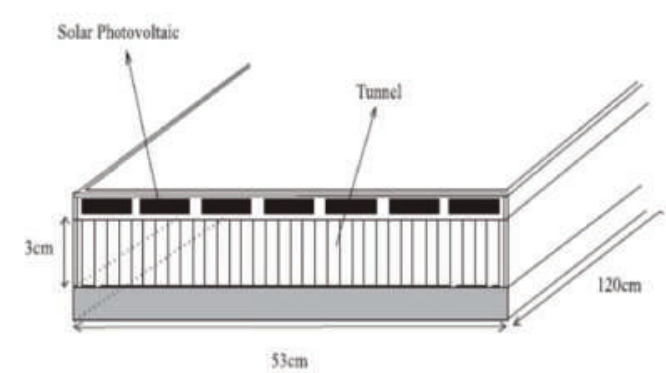

Figure 10. Schematic diagram of the PV/T collector with rectangular tunnel absorber [33].

\section{Experimental yield of different combined hybrid PV-thermal designs}

Have been working many test orders to improve the overall efficiency of solar energy devices by taking advantage of the heat discharged from the PV module system and use in other fields, in other hand increase the efficiency by absorbing the high temperatures from PV cell and achieve a higher energy conversion ratio of the absorbed solar radiation. [36], in addition the research has been conducted in PV/T associated with heating and cooling facilities and the thermal energy from the water-type PV/T collector systems, which can be used in buildings, and a solar collector for domestic hot water and space heating [37], which is similar in manufacturing to conventional thermal solar energy collector, Which can be achieved by circulating cooler fluid, water or air, by along the underside of the PV module PV/T collectors can be classified according to the type of working fluid used (water, air or both). Most studies that examine the performance include estimates of the different types of panel absorption, such as sheet and tube, completely wet and the channel box types, analysis of several different types of collectors $\mathrm{PV} / \mathrm{T}$ (sheet and tube, channel, free-flowing dual absorption), as shown in Figure 11 [38]. The experimental results indicated that the overall gain heat from the collector is $9.7 \mathrm{kWh}$, while the average thermal and electrical efficiency of the system is $30 \%$ and $17 \%$ respectively. It was also shown that the heating energy of the house can be reduced by $47 \%$, and the heat gained from the integrated roof $\mathrm{PV} / \mathrm{T}$ system by the water used for heating in the heating system, this means that the energy required in the building can be reduced dramatically by $47 \%$ at a temperature of water heating from $40^{\circ} \mathrm{C}$ heats. Therefore, it can be concluded that this system can reduce the energy required for igniting the building by nearly half by heating water and heating at low temperatures. Related to electrical efficiency and the highest level of performance, with an efficiency exceed $16.5 \%$ when the heating system with BIPVT (Building Integration photovoltaic/thermal) collector was working, has happened because the relatively low temperatures of liquid which had been circulated. So, the system very suitable to increase the energy performance of buildings also confirmed that the water temperature of the thermal storage tank [39].
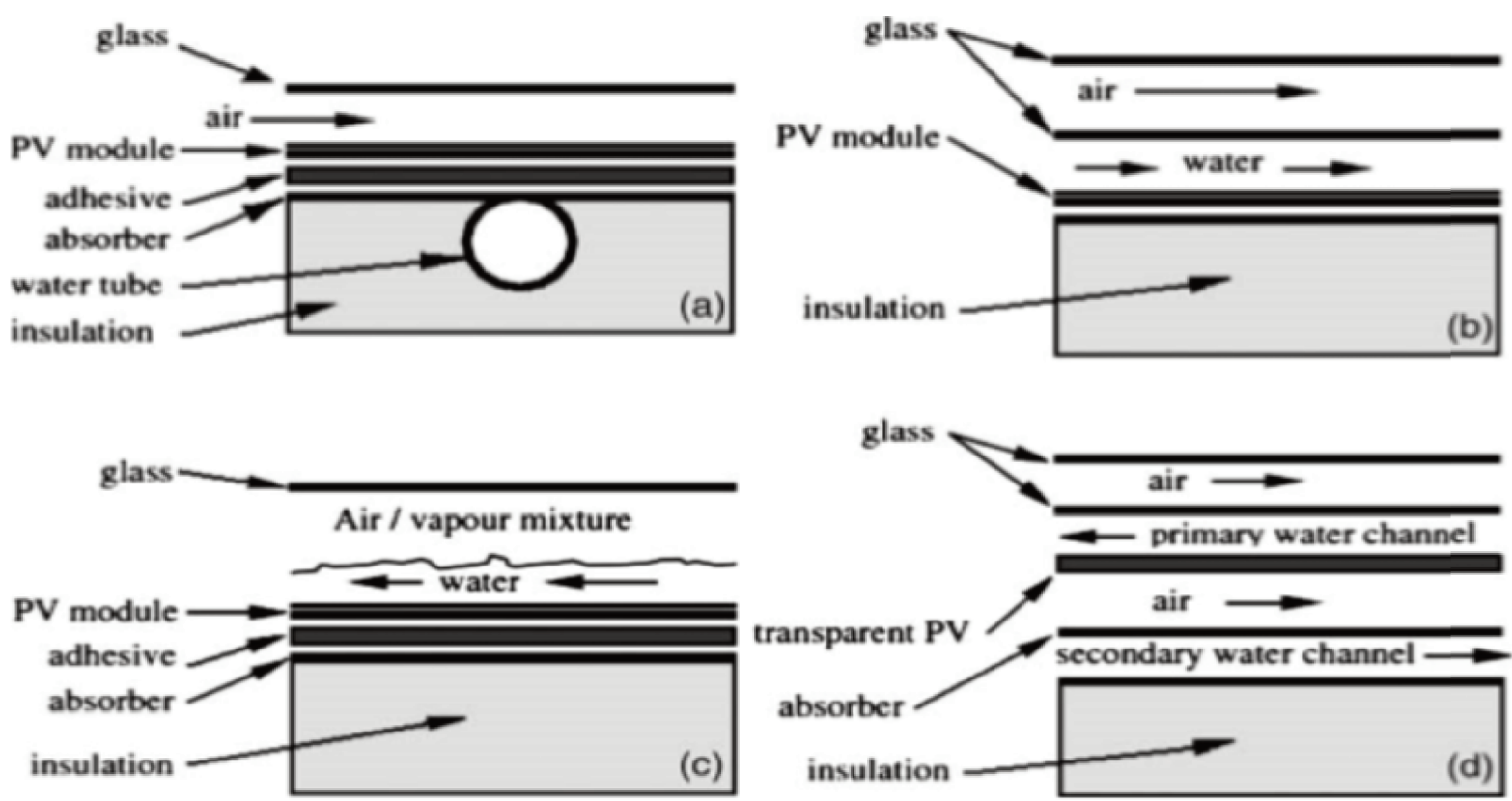

Figure 11. Types of PVT Collectors: Sheet-and-Tube (a), Channel (b), Free-Flow (c) and Dual-Absorber (d) [39] 


\section{Conclusion}

Performance evaluation of (PV/T) hybrid systems for a lot of experiments were various where the amount of falling solar radiation, design, orientation and selection type solar cell, all of that plays essential role in the amount of energy produced. Where found during this study receive more direct exposure to solar radiation that will effect on the work of (PV) modules by increase temperature and drop the efficiency of solar cells. Therefore, use hybrid photovoltaic/thermal (PV/T) collector with mediums such as (water or air) will contribute to raising system efficiency during the absorption of excess heat from solar cells, and avoid the high temperatures absorbed by (PV) modules by the piping that fixed in the face back of the panel and take the advantage of heat which absorbed for household applications or heating purposes. That led to increase the rate return of the system of electricity and thermal energy, where contribute to a large extent to strengthen the work of solar cells, system efficiency and the conversion rate of absorbed solar radiation for (PV) modules will increase as well, especially when the hybrid photovoltaic/thermal (PV/T) solar systems were properly designed.

\section{Acknowledgments}

The author wishes to thank the support of the Southern Technical University for providing facilities for this paper. The researcher is grateful to have the support from (Hayder A. Alrazen and Qudama AlYasiri).

\section{References}

[1] Krauter S., Hanitsch R.: 1994. Actual optical and thermal performance of PV-thermal modules. In Proceedings of the First Conference on Photovoltaic Energy Conversion, Hawaii pp. 734-37.

[2] Al-ktranee M. H. R., Schrempf N.: 2016. Hybrid solar system (photovoltaic/thermal) utilization for household application. Hungarian Agricultural Engineering, Vol. 30, pp. 54-61.

http://dx.doi.org/10.17676/HAE.2016.30.54

[3] Saitoh H., Hamada Y., Kubota H., Nakamura M., Ochifuji K., Yokoyama S., Nagano K.: 2003. Field experiments and analyses on a hybrid solar collector. Applied Thermal Engineering, Vol. 23, No. 16, pp. 2089-2105. http://dx.doi.org/10.1016/S1359-4311(03)00166-2 [4] Elazari A.: 1998. Multi Solar System Solar multi module for electrical and hot water supply for residentially building/ In Proc. 2nd World Conf. on
Photovoltaic Solar Energy Conversion. pp. 24302423.

[5] Mei L.: 2003: Thermal modeling of a building with an integrated ventilated PV façade. Energy and buildings, Vol. 35, No. 6, pp. 605-617.

http://dx.doi.org/10.1016/S0378-7788(02)00168-8

[6] Fraisse G., Souyri B.: 2003. Rapport Programme Energie CNRS: "Compte rendu scientifique: conception d'un capteur PV/T - eau. Rapport premie're anne'e. PRI 6.2. Inte'gration de capteurs hybrides photovoltai" ques thermiques au ba^ ti, pp. 56.

[7] Loferski J. J., Ahmad J. M., Pandey A.: 1988. Performance of photovoltaic cells incorporated into unique hybrid photovoltaic/thermal panels of a 2.8 $\mathrm{kW}$ residential solar energy conversion system/In Proceedings of 1988 annual meeting. American Solar Energy Society. Cambridge, USA, pp. 427-32.

[8] Garg H. P., Adhikari R. S.: 1997. Conventional hybrid photovoltaic/thermal (PV/T) air heating collectors. steady-state simulation. Renewable Energy, Vol. 11, No. 3, pp. 363-85.

http://dx.doi.org/10.1016/S0960-1481(97)00007-4

[9] Charalambous P. G., Maidment G. G., Kalogirou S. A., Yiakoumetti K.: 2007. Photovoltaic Thermal (PV/T) collectors: A review. Applied Thermal Engineering, Vol. 27, No. 2-3, pp. 275-286.

http://dx.doi.org/10.1016/j.applthermaleng.2006.06.007 [10] Florschuetz L. W.: 1979. Extension of the Hottel-Whillier model to the analysis of combined photovoltaic/thermal flat plate collectors. Solar Energy, Vol. 22, No. 4, pp. 361-6.

http://dx.doi.org/10.1016/0038-092X(79)90190-7

[11] Raghuraman P.: 1981. Analytical predictions of liquid and air photovoltaic/thermal, flat-plate collector performance. Journal of Solar Energy Engineering, Vol. 103, No. 4, pp. 291-298.

http://dx.doi.org/10.1115/1.3266256

[12] Cox C. H. III., Raghuraman P.: 1985. Design considerations for flat-plate photovoltaic/thermal collectors. Solar Energy, Vol. 35, No. 3, pp. 227-241. http://dx.doi.org/10.1016/0038-092X(85)90102-1

[13] Dupeyrat P., Ménézob C., Fortuinc S.: 2012. Study of the thermal and electrical performances of PVT solar hot water system. Energy and Buildings. Vol. 68, Part C, pp. 751-755.

http://dx.doi.org/10.1016/j.enbuild.2012.09.032

[14] Vries D. W.: 1998. Design of a Photovoltaic/ Thermal Combi-panel. PhD thesis. Eindhoven University of Technology. Netherlands.

[15] Kalogirou S. A.: 2001. Use of TRNSYS for modeling and simulation of a hybrid pv-thermal solar system in Cyprus. Renewable Energy, Vol. 23, No. 2, pp. 247-260.

http://dx.doi.org/10.1016/S0960-1481(00)00176-2 
[16] Imre L., Bitai A., Bohonyey F., Hecker G., Palfy M.: 1993. PV-thermal combined building elements. Proceedings of ISES Solar World Congress, pp. 80-277.

[17] Bosanac M., Sørensen B., Katic I., Sørensen H., Nielsen B., Jamal Badran J.: 2003. Photovoltaic/Thermal Solar Collectors and Their Potential in Denmark. EFP project 1713/00-0014, Final Report, pp. 114.

[18] Hendrie SD.: 1979. Evaluation of combined photovoltaic/thermal collectors. In Proceedings of the international conference ISES, Vol. 3, Atlanta, Georgia, USA, pp. 1865-1869.

[19] Kern E. C. Jr., Russel M. C.: 1978. Combined photovoltaic and thermal hybrid collector systems. In Proceedings of the 13th IEEE photovoltaic specialists. Washington DC, USA, 1978, pp. 11531157.

[20] Kalogirou S. A., Tripanagnostopoulos Y.: 2006. Hybrid PV/T solar systems for domestic hot water and electricity production. Energy Conversion and Management, Vol. 47, No. 18-19, pp. 368-3382. http://dx.doi.org/10.1016/j.enconman.2006.01.012

[21] Sorensen H., Munro D.: 2000. Hybrid PV/thermal collectors. In The EN World Solar Electric Buildings Conference. Sydney, 2000, pp. 1-7.

[22] Fraisse G., Menezo C., Johannes K.: 2007. Energy performance of water hybrid PV/T collectors applied to combisystems of Direct Solar Floor type. Solar Energy, Vol. 81, No. 11, pp. 1426-1438. http://dx.doi.org/10.1016/j.solener.2006.11.017

[23] Affolter P., Ross D., Toggweiler P., Haller A.: 2000. New generation of hybrid solar PV/T collectors/ Final Report DIS 56360/16868, pp. 55.

[24] Soteris K.: 2003. The potential of solar industrial process heat applications. Applied Energy, Vol. 76, No. 4, pp. 337-361.

http://dx.doi.org/10.1016/S0306-2619(02)00176-9

[25] Bergene T., Lovvik M. O.: 1995. Model calculations on a flat-plate solar heat collector with integrated solar cells. Solar Energy, Vol. 55, No. 6, pp. 453-462.

http://dx.doi.org/10.1016/0038-092X(95)00072-Y

[26] Erdil E., Ilkan M., Egelioglu F.: 2008. An experimental study of energy generation with a photovoltaic (PV) - solar thermal hybrid system. Energy, Vol. 33, No. 8, pp. 1241-1245.

http://dx.doi.org/10.1016/j.energy.2008.03.005

[27] Klugmann E.: 2000. Influence of temperature on conversion efficiency of a solar module working in photovoltaic PV/T-integrated system/ photovoltaic solar energy conference. Glasgow, UK, pp. 1-5.

[28] Kumar S., Tiwari A.: 2010. Design, fabrication and performance of a hybrid photovoltaic/thermal
(PV/T) active solar still. Energy Conversion and Management, Vol. 51, No. 6, pp. 1219-1229. http://dx.doi.org/10.1016/j.enconman.2009.12.033

[29] Singh G., Kumar S., Tiwari G. N.: 2011. Design, fabrication and performance evaluation of a hybrid photovoltaic thermal (PVT) double slope active solar still. Desalination, Vol. 277, No. 1-3, pp. 399-406.

http://dx.doi.org/10.1016/j.desal.2011.04.064

[30] Chow T. T.: 2010. A review on photovoltaic/thermal hybrid solar technology. Applied Energy, Vol. 87, No. 2, pp. 365-379. http://dx.doi.org/10.1016/j.apenergy.2009.06.037

[31] Prakash J.: 1994. Transient analysis of a photovoltaic-thermal solar collector for co-generation of electricity and hot air/water. Energy Conversion Management, Vol. 35, No. 11, pp. 967-972.

http://dx.doi.org/10.1016/0196-8904(94)90027-2

[32] Ruslan M. H., Othman M. Y., Spain K., Majid Z. A. A., Him W. A.: 2008. Development of photovoltaic-thermal (PV/T) water based system. World of Renewable Energy, Glasgow, pp. 352-365. [33] Othman M. Y., Ibrahim A., Jin G. L., Ruslan M. H., Sopian K.: 2013. Photovoltaic-thermal (PV/T) technology - The future energy technology. Renewable Energy, Vol. 49, pp. 171-174. http://dx.doi.org/10.1016/j.renene.2012.01.038

[34] Kalogirou S. A., Tripanagnostopoulos Y.: 2007. Industrial application of PV/T solar energy systems. Applied Thermal Engineering, Vol. 27, No. 8-9, pp. 1259-1270.

http://dx.doi.org/10.1016/j.applthermaleng.2006.11.0 03

[35] Liang R., Zhang J., Zhoua C.: 2015. Dynamic Simulation of a Novel Solar Heating System Based on Hybrid Photovoltaic/Thermal Collectors (PVT). Procedia Engineering, Vol. 121, pp. 675 - 683. http://dx.doi.org/10.1016/j.proeng.2015.09.001

[36] Institute for Building Energy Conservation.: 1992. The Course of Low Energy Houses and Buildings. Japanese. IBEC, Vol. 67, pp. 68-75.

[37] Hokkaido.: 1998. Government Financial Assistance for Energy Conservation.

[38] Zondag H. A., de Vries D. W., van Helden W. G. J., van Zolingen R. J. C., van Steenhoven A. A.: 2003. The yield of different combined PV-thermal collector designs. Solar Energy, Vol. 74, No. 3, pp. 253-269.

http://dx.doi.org/10.1016/S0038-092X(03)00121-X

[39] Kim J. H., Kim J. T.: 2016. Performance Analysis of Roof-Integrated Water-Type PVT Heating System. International Journal of Smart Home, Vol. 10, No. 3, pp. 301-314.

http://dx.doi.org/10.14257/ijsh.2016.10.3.29 